\title{
EFFECTS OF BAROTRAUMA ON FOUR SPECIES OF PACIFIC ROCKFISHES (SEBASTES SPP.)
}

\author{
A Thesis \\ presented to \\ the Faculty of California Polytechnic State University, \\ San Luis Obispo
}

\author{
In Partial Fulfillment \\ of the Requirements for the Degree \\ Master of Science in Biological Sciences
}

by

Lesley Marie Salter

May 2019 
(C) 2019

Lesley Marie Salter

ALL RIGHTS RESERVED 


\section{COMIMITTEE MEMBERSHIP}

TITLE: Effects of Barotrauma on Four Species of Pacific

Rockfishes (Sebastes Spp.)

AUTHOR: $\quad$ Lesley Marie Salter

DATE SUBMITTED: May 2019

COMMITTEE CHAIR: Ben Ruttenberg, Ph.D.

Associate Professor of Biological Sciences

COMMITTEE MEMBER: Dean Wendt, Ph.D.

Dean of College of Science and Mathematics

COMMITTEE MEMBER: Sean Lema, Ph D.

Associate Professor of Biological Sciences 


\begin{abstract}
Effects of Barotrauma on Four Species of Pacific Rockfishes (Sebastes Spp.) Lesley Marie Salter
\end{abstract}

Physoclistic fish, such as Pacific rockfishes (genus Sebastes), have closed swim bladders that help them regulate their buoyancy. When anglers catch these fish and reel them to the surface, gases within their swim bladder expand due to the decrease in pressure. This can cause their swim bladder to over inflate-a condition known as barotrauma. Overly buoyant fish experiencing barotrauma often struggle to swim back to dwelling depth if released at the ocean's surface. These fish may experience high rates of mortality by thermal shock caused by the warmer surface temperatures, starvation, predation, or vision problems caused by barotrauma. Assisted release methods that recompress fish by returning them to depth prior to release may thus greatly improve survival of fish suffering from barotrauma.

In this study, I characterized species-specific responses of four species of nearshore Pacific rockfishes (Canary Rockfish, Sebastes pinniger; Gopher Rockfish, $S$. carnatus; Deacon Rockfish, S. diaconus; and Blue Rockfish, S. mystinus) to rapid ascent by hook-and-line fishing from shallow depths $(<40 \mathrm{~m})$. I videotaped their immediate responses upon recompression using a weighted inverted milk crate to transport fish back to their initial capture depth. Fish were videotaped during their descent, as well as their release from the crate. In some individuals, barotrauma symptoms were reversed and did not show behavioral impairment upon release, indicating that even a simple, inexpensive device can be effective in relieving barotrauma symptoms. Species differences were also observed in the severity of barotrauma observed following the collection of fish from 
depth. Capture depth was positively correlated with the occurrence of barotrauma for Blue Rockfish and Gopher Rockfish, but not for Canary Rockfish or Deacon Rockfishes. I utilized data over an eight-year period from the California Collaborative Fisheries Research Project (CCFRP) to assess survivorship of rockfish experiencing barotrauma. A total of 20 rockfish (1 Black Rockfish, S. melanops; 2 Blue Rockfish; 12 Gopher Rockfish; 3 Copper Rockfish, S. caurinus; and 2 Kelp Rockfish, S. atrovirens) initially displaying barotrauma signs upon capture were tagged using a T-bar tag and released. It is unknown if these fish were recompressed because the CCFRP did not record this information. These 20 rockfish were recaptured days to 3 years laterindicating rockfish can survive long term after experiencing barotrauma. To minimize mortality of discarded fish in the fishery, fish recompression is recommended. 


\section{ACKNOWLEDGMENTS}

Thank you, Ben Ruttenberg, for all of your amazing guidance and support. Thank you to my committee members, Sean Lema and Dean Wendt for guiding me with your expertise. Thank you, Royden Nakamura for your encouragement and wisdom. Thank you Eric Anderson, Natasha Meyers-Cherry, Morgan Ivens-Duran, and Paul Carvahlo, for your support and help with data collection on Cal Poly's California Collaborative Research Project. Grant Waltz, I cannot thank you enough for your guidance, superior editing, and good humor. John Viggianelli, thank you for using your expert fishing skills to help me develop the descending device. Thank you, Doug and Rob Brewster for helping design and create the Barotrauma Reliever. Nicole Broquet, thank you for helping me organize my data and watching countless videos of rockfish behavior. Andrew Schaffner and Lauren Kemp from the Cal Poly Statistic Department, thank you immensely for helping me analyze my results. Thank you captains, deckhands, volunteer anglers, Virg's Sportfishing, and Patriot Sportfishing, who allowed me on your boats and shared insightful knowledge with me. This research was supported by California Sea Grant, California Polytechnic State University College of Science and Math, the David and Lucile Packard Foundation, Resources Legacy Fund Foundation, the California Coastal Conservancy, and the California Ocean Protection Council. 


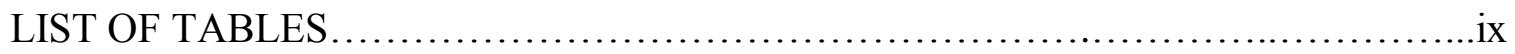

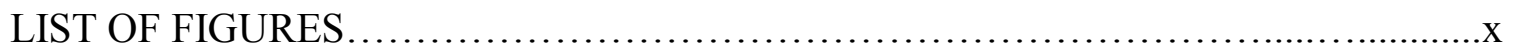

\section{CHAPTER}

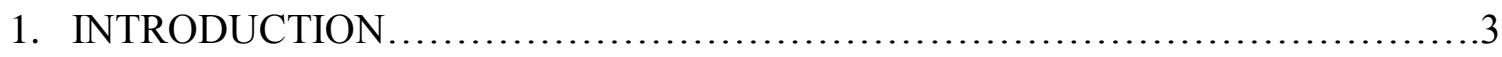

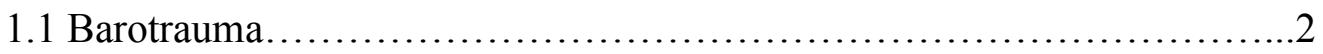

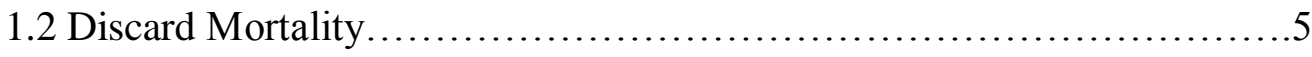

1.3 Rockfish as a Model Organism for Studying Barotrauma..................7

1.4 Hypothesis and Predictions......................................... 9

2. METHODS.........................................................................

2.1 Evaluation of the Frequency of Barotrauma in Pacific Rockfishes..........11

2.2 Recapture of Tagged Fish to Assess Survivorship.....................12

2.3 Descending Device.............................................. 12

2.4 Recompression..................................................

2.5 Analysis........................................................ 15

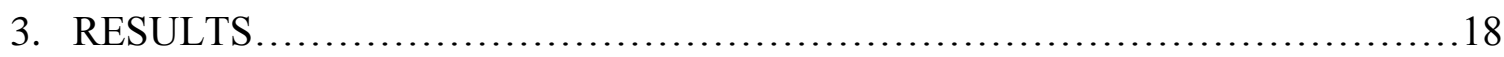

3.1 Incidences of Barotrauma Among Rockfish Species.....................18

3.2 Incidences of Barotrauma Among Rockfish Species and Relationships

to Depth of Capture................................................ 18

3.3 Incidences of Barotrauma Among Rockfish Species in Relation to

Temperature and Fish Size..........................................20

3.4 Behavior of Fish Following Release................................20 
3.5 Survival of Fish Following Release..............................21

3.6 Recompression System Effectiveness..............................21

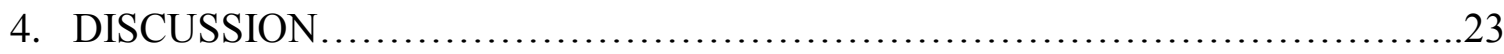

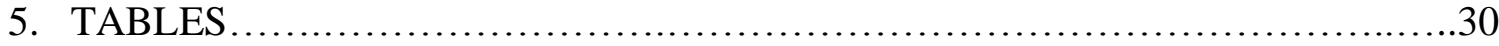

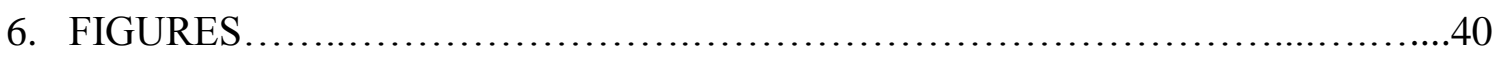

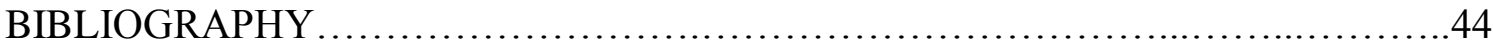




\section{LIST OF TABLES}

Table

Page

1. Abbreviations and Descriptions of Observed Barotrauma Symptoms.................28

2. Scoring System for Mean Immediate Behavioral Composite Scores........................29

3. Frequency of Four Species of Pacific Rockfish Displaying Barotrauma.................30

4. Output of Logistic Regression Analysis of the Proportion of Pacific Rockfishes Displaying Symptoms of Barotrauma in Relation to Capture Depth by Species....................................................... 31

5. Summary of Kruskal-Wallis Test........................................ 32

6. Summary of Wilcoxon Each Pair Test......................................... 33

7. Proportions of Mean Immediate Behavioral Composite Scores for Canary, Gopher, Deacon, and Blue Rockfish.

8. Summary of Wilcoxon each Pair Test Results from the Mean Immediate Composite Scores in Table 7

9. Total Recaptured Pacific Rockfish Displaying Barotrauma and Exhibiting Long-term Survival .36

10. Proportions of Rockfish Displaying Barotrauma Symptoms and Swimming Behavior After Recompression. 


\section{LIST OF FIGURES}

$\begin{array}{lll}\text { Figure } & \text { Page }\end{array}$

1. Sampling Sites for Pacific Rockfish off the Central California Coast..................38

2. Weighted Inverted Milk Crate Descending Device (Barotrauma Reliever)...............39

3. Fitted Logistic Regression Curve Analyzing Correlation of Blue Rockfish

Exhibiting Barotrauma in Relation to Capture Depth..................................40

4. Fitted Logistic Regression Curve Analyzing Correlation of Gopher Rockfish

Exhibiting Barotrauma in Relation to Capture Depth ............................41 


\section{INTRODUCTION}

In California, approximately $22 \%$ of the state's population participates in recreational fisheries, and 1,725,423 people possessed a sport fishing license in 2018 (California Department of Fish and Wildlife, 2019). Despite the strong public interest in recreational fishing, the management of reactional fisheries is challenging because fishing effort is diffuse and targets a wide range of species, making data on the impact of recreational fishing on fish populations difficult to collect (Cooke and Cowx, 2004; National Oceanic and Atmospheric Administration, 2019). The population status of species can influence the restrictions on recreational fisheries. Incidental catch from recreational anglers can decline fish populations (Cooke and Cowx, 2004; Coleman et al., 2004; Lewin et al., 2006), which is why fishing regulations are implemented based on the population status of the species (Worm et al., 2009; National Oceanic and Atmospheric Administration, 2019). While new management approaches are beginning to be developed and applied, recreational fishery management strategies have traditionally relied on simple management tools such as bag limits and catch and release restrictions to protect the fish population (Brownscombe et al., 2019; Cooke, et al., 2017; Pikitch et al., 2004; Smith et al., 2007; Schnute, et al., 2007; Worm et al., 2009; National Oceanic and Atmospheric Administration, 2019). But it's difficult to regulate catch and release fishing because there's limited data on the amount of people practicing catch and release and the mortality associated with this type of fishing (Cooke and Cowx, 2004). In 2015, 1 billion fish were caught by recreational anglers in America with $64 \%$ of those fish released alive (National Oceanic and Atmospheric Administration, 2019). While restricting recreational fishing to catch-and-release seems like a good solution to increase fish populations, in 
practice mortality from catch-and-release angling can be high because fish may be injured from the hook or angler or suffer less obvious physiological or behavioral impairments from the sublethal stresses of handling and air exposure following capture (Campbell et al., 2010; Cooke and Philipp, 2001; National Oceanic and Atmospheric Administration, 2019). Indeed, such post-release mortality and sublethal effects have led to questions about whether even catch-and-release recreational angling may be too detrimental for some fish populations of conservation concern, or for achieving management goals in some locales such as Marine Protected Areas (MPAs) (e.g., Cooke et al., 2006). Additionally, with such high rates of fish being released after capture, it is important to know the survival rates of released fish to ensure stock assessments are accurately predicted.

The unintended impacts of recreational catch-and-release fishing is of particular concern for some nearshore marine fishes that can be prone to barotrauma. When fish with an enclosed swim bladder are rapidly brought to the surface, gases expand within the swim bladder during ascent due to a rapid decrease in pressure (California Department of Fish and Wildlife, 2019; Sumpton, 2010). These gases remain trapped in the swim bladder, making the fish positively buoyant — a condition known as barotrauma. (California Department of Fish and Wildlife, 2019; Rodgveller et al. 2017). Therefore, when a fish is released back to the water's surface, they cannot swim back down to depth—potentially leading to death by thermal shock, starvation, or predation (Hannah and Matteson, 2007; Hannah et al., 2011; Hochhalter and Reed, 2011; Jarvis and Lowe, 2008; Parker et al., 2006; Rodgveller et al., 2017). 


\subsection{Barotrauma}

Many fish have a swim bladder, an internal gas-filled organ that helps maintain a fish's neutral buoyancy. Physostomous fish have "open” swim bladders that are connected to the intestine via a duct to the digestive tract, whereas physoclistic fish have a "closed" swim bladder with no duct leading out of the body from the swim bladder (Sumpton, 2010). Extreme changes in pressure can affect how fish normally regulate their buoyancy (Sumpton, 2010). When physoclistic fish are rapidly brought to the surface by anglers, gases expand within the swim bladder due to a rapid decrease in pressure. Gases in the swim bladder organ adhere to Boyle's Law, which states that the volume of a gas is related proportionally to its pressure. A decrease in hydrostatic pressure thus causes the volume of gases in the swim bladder to increase. For example, every 10 meters of water depth, pressure increases by 1 atmosphere. Thus at 40 meters deep, the pressure is 4 times greater than at the surface (Curtis et al., 2015). Therefore, if the fish was brought to the surface, the volume in the swim bladder could increase by a factor of 4 (Curtis et al., 2015). Again, following from Boyle's Law, the volume change for gas expansion increases for fish ascending rapidly over a given vertical distance, meaning that barotrauma can be common even for fish caught in shallower, nearshore environments, which are often targeted more frequently by recreational fisheries.

The increased volume of gases in the swim bladder when fish are brought rapidly to the ocean's surface from depth can limit space in the body cavity for other organs. Gases expanding within an over-inflated swim bladder can also diffuse through the swim bladder wall and escape into the skull and other regions of the body (Rummer and Bennett 2005). This process can cause displacement or damage to other organs by 
stretching or crushing them. Furthermore, this can lead to a series of detrimental effects; e.g., tight abdomen, swim bladder over inflation, swim bladder rupture, everted esophageal tissue, exophthalmia, corneal emphysema, or protrusion of anal glands -all of which can be classified as symptoms of barotrauma (Parker et al., 2006; Burns and Restrepo, 2002). The esophageal tissue in the stomach can evert beyond the buccal cavity if the swim bladder inflates so much that it pushes the esophageal tissue out of the fish's mouth (Hannah, 2012; Rodgveller et al., 2017). Corneal emphysema occurs when gas is present within the eye or the connective tissue surrounding the eye (Hannah, 2012). Anal glands can evert outside of the body due to the lack of space within the fish's body due to an overinflated swim bladder (Hannah, 2012; Burns and Restrepo, 2002). And most concerning, a tight abdomen or over-inflated swim bladder can lead to a ruptured swim bladder if the swim bladder cannot withstand the amount of air within it (Hannah, 2012).

Without assistance to release fish back at depth using a weighted descending device or barbless weighted hook - instead of release at the ocean surface - it is extremely difficult for these fish to swim back down to depth. This can decrease their probability of survival, as they are more prone to internal physical trauma, thermal shock, predation by pinnipeds or seabirds, or starvation (Rodgveller et al., 2017; Hochhalter and Reed, 2011; Jarvis and Lowe, 2008). Physostomous fish rarely experience barotrauma because they can "burp" out the expanded air in the swim bladder since it is connected to the esophagus. Barotrauma is an issue for physoclistic fish because they do not have a biological mechanism to release the trapped gases in their swim bladder (Jarvis and Lowe, 2008). 
Some studies have observed that fish caught at deeper depths are more negatively affected by barotrauma than fish captured at shallower depths (Wilson and Burns, 1996; Morrissey et al., 2005; St. John Syers, 2005). Jarvis and Lowe (2008) observed that responses to barotrauma and recompression were species-specific in rockfish. Individual fish of the same species can respond to barotrauma differently due to slight differences in length, width, mass, size of the organs, and the specific context of temperature changes during ascent (Jarvis and Lowe, 2008). Thus, it is important to investigate how barotrauma affects different species of rockfish, rather than assuming they respond similarly.

\subsection{Discard Mortality}

About $60 \%$ of fish caught are discarded back to the ocean and are not included in landing records (Cooke and Cowx, 2004; Bartholomew and Bohnsack, 2005). Sometimes there are restrictions on the number of fish retained (bag limit) or the size of fish (length limit). While these regulations are intended to control the total amount of harvested fish, they can increase the rate of discarded fish-which may also increase the number of fish released with barotrauma. Fish that are required to be returned to the ocean include restricted species and fish smaller or larger than the allowed length limit, species of conservation concern, and juvenile fish, therefore these fish may make up a disproportionately high amount of released fish with barotrauma (Benoît et al., 2013). While legal regulations can be used to control the amount of fish retained by recreational fishers, regulations are less effective at controlling the amount of by-catch, such as undersized and unwanted fish being discarded in the ocean. It is extremely difficult to 
avoid catching illegal or undesirable species when they live in mixed fish communities with fish that are allowed to be retained (Davis, 2002).

Additionally, when unwanted and regulation-restricted fish are caught, there are no regulations on how they are to be released. The fish are not required to be recompressed and transported back to the initial capture depth. Therefore, if fish have barotrauma, their probability of survival can decrease due to their buoyancy on the surface of the water (Jarvis et al., 2008; Hannah and Matteson, 2007; Hannah et al., 2008a, Hannah et al., 2008b, Hochhalter and Reed, 2011). However, if fish are immediately transported to depth, the gases can recompress within the swim bladderallowing the swim bladder to return to its initial volume (Roger, 2008). Such recompression can greatly improve survival and reduce the non-lethal impacts of barotrauma (Rodgveller et al., 2017; Drumhiller et al., 2014; Jarvis et al., 2008; Pripyl et al., 2012). Therefore, it is crucial to assess how recreational, commercial, threatened, and endangered species respond to barotrauma (e.g., Butcher et al., 2010, 2012). It is equally important to understand the survivorship of fish that have barotrauma and are recompressed. In turn, these results may pave the path for potential effective discard practices to decrease discard mortalities.

There are various devices and techniques used to descend fish, such as the Shelton Fish Descender (Shelton Products; Newark, CA, USA), RokLees (EcoLesser, La Mesa, CA, USA), Blacktip (West Marine; Santa Barbara, CA, USA), SeaQualizer (Florida, CA, USA), and complex cages (California Department of Fish and Wildlife, 2019). Some anglers do not use these types of fish descenders because they are expensive, cannot be made by the anglers, are complex to use, or do not successfully transport fish to the 
desired depth (Hazell et al., 2016). Descending fish also takes time and effort, and anglers may not want to take the time to descend a fish when they can release it at the surface within seconds (Hazell et al., 2016). Additionally, anglers may not be aware of descending devices or are not educated about barotrauma, in which case they do not use descending devices (Hazell et al., 2016). In short, experimental evidence demonstrating the success of recompression at aiding the symptoms of barotrauma and improving fish survival post-release is crucial for justifying a boarder application of fish descenders by recreational anglers.

Additionally, a more invasive technique called 'venting' involves puncturing the swim bladder with a hypodermic needle to release the gases in the swim bladder. By releasing the gases, the fish becomes less buoyant, which makes it easier for the fish to swim to depth on its own (Brusewitz et al., 1993; Keniry et al., 1996; Collins et al., 1999). This recompressing method is the fastest, but is controversial because it requires skill to properly puncture the swim bladder, and not mistakenly puncture a vital organ (Kerr, 2001). The healing process after venting is unknown, and infections can occur (Kerr, 2001). Therefore, less invasive practices are preferred to recompress rockfish (Rankin et al., 2017).

\subsection{Rockfish as a Model Organism for Studying Barotrauma}

Pacific rockfishes (Sebastes spp.) are model organisms for studying barotrauma because they are physoclistic fish, recreationally and commercially important fish in the Northern Pacific Ocean, and certain species are threatened (Yoklavich et al., 2007; Parker et al., 2000; Olson et al., 2017). Some rockfish species are overfished and have noretention laws, while others are recovering and have low allowed catch limits, and some 
seem to have healthy populations (Rankin et al., 2017). In the rockfish fishery, there are regulations on the bag limit, fishing depth, and seasonal and spatial restrictions.

In this study, I focused my research on Canary Rockfish (Sebastes pinniger), Gopher Rockfish (Sebastes caratus), Deacon Rockfish (Sebastes diaconus), and Blue Rockfish (Sebastes mystinus). I chose to study Canary Rockfish because they are a species of concern; thus, it is especially important to decrease their discard mortality (California Department of Fish and Wildlife, 2019). Anglers are allowed to retain a maximum of two Canary Rockfish per day, compared to ten per day for species that are not of concern (California Department of Fish and Wildlife, 2019). Canary Rockfish are long, thin, larger in head size, and commonly found between 80-200m (Love, et al., 2002). I studied Gopher Rockfish because their response to barotrauma has never been studied. Gopher Rockfish are deeper bodied, and are found from intertidal waters to $80 \mathrm{~m}$, however most live deeper than 12m (Love, et al., 2002). Deacon (also known as Northern Blue or Blue-sided) and Blue Rockfish (also known as True Blue or Blue Blotch) have never been analyzed separately when investigating effects of barotrauma. The two species were officially recognized as different species in June 2015 (Frable et al., 2015). Deacon and Blue Rockfish look similar; however, Deacon Rockfish are generally darker in color and have a distinct speckling pattern on the trunk (Frable et al., 2015). Deacon Rockfish have a more elongated body with a flatter underside (Frable et al., 2015). Blue Rockfish are generally lighter colored, have blotched patterns on their sides, and have a more rounded body (Frable et al., 2015). While both species are found in similar depth ranges from the intertidal to $90 \mathrm{~m}$, Deacon Rockfish are generally found further from the coast than Blue Rockfish (Frable et al., 2015). Therefore, Deacon Rockfish are caught at 
slightly deeper depths than Blue Rockfish because Blue Rockfish are found closer to the coast in slightly shallower waters (Frable et al., 2015). These four species represent the larger group of Sebastes spp. because they occupy different regions, different parts in the water column, and have various body shapes. By studying these diverse rockfish species, educated predictions can be made on other species of rockfish that are morphologically and ecologically similar to one of these species.

\subsection{Hypothesis and Predictions}

In this study, I characterized species-specific responses to rapid ascent by hookand-line fishing from shallow depths $(<40 \mathrm{~m})$, and analyzed the fish's response upon immediate recompression. First, I collected frequency data of nearshore Pacific rockfish species experiencing barotrauma at various depths. I also inspected recapture rates of tagged-and-released fish that did and did not have barotrauma. This long-term survival data sheds light on if and how long rockfishes may survive after experiencing barotrauma. Second, I tested a simple and inexpensive method of recompression (a weighted inverted milk crate- called the Barotrauma Reliever; California Department of Fish and Wildlife, 2019) to examine how effective recompression is for alleviating barotrauma symptoms in Pacific rockfishes. By pairing the use of this Barotrauma Reliever recompression method with a camera system, I observed and assessed any immediate behavioral impairments after fish were recompressed from barotrauma.

Even though all fish studied here belong to genus Sebastes spp., these species are expected to vary in the frequency, severity and survival impacts from experiencing barotrauma, as they vary in mass, length, body shape, and inhabit different depths in the water (Love et al., 2002). Specifically, I predict Blue and Deacon Rockfish to be the least 
prone to barotrauma since they are known to live more in the middle of the water column than on the seafloor. Blue Rockfish should respond similarly to Deacon Rockfish since they are the most closely related species of the four I am studying. I expect Canary Rockfish to be the most sensitive to barotrauma since they are a benthic species and are typically caught at the deepest depths of my sample population (Love et al., 2002). Therefore, Canary Rockfish would experience the greatest change in pressure when caught compared to Deacon, Blue, and Gopher Rockfish. I predict Gopher Rockfish to be less prone to barotrauma than Canary, but more sensitive compared to Blue and Deacon Rockfish since they live between their depth ranges. I also hypothesize the simple and inexpensive Barotrauma Reliever will transport fish back down to depth, allowing them to recompress the gases within their body. In turn, the rockfish experiencing barotrauma should swim away from the Barotrauma Reliever upon release, indicating they are not impaired from barotrauma. Overall, this study will provide useful information to help inform management decisions regarding the issue of rockfish discard mortality. 


\section{METHODS}

Canary Rockfish (N=62; 13-39 cm FL), Gopher Rockfish (N=414; 16-34 cm FL), Deacon Rockfish (N=119; 16-34 cm FL), and Blue Rockfish (N=555; 7-40 cm FL), were targeted in this study. Sampling took place off the Central Coast of California, USA. The California Collaborative Fisheries Research Project (CCFRP) is a standardized hook-andline monitoring project designed to investigate the efficacy of Marine Protected Areas (MPAs). CCFRP conducts groundfish sampling in the Point Buchon and Piedras Blancas MPAs and at reference sites just outside the MPAs along the coast of Central California each summer (Figure 1; Starr et al., 2015). Sebastes spp. and other recreationally important species are targeted in their study. I utilized the rockfish caught by CCFRP anglers for this study on barotrauma. CCFRP fishing methods are designed to replicate common recreational practices. Therefore, hook-and-line methods with bait or flies were used to target rockfish (for a detailed description of the methods see Starr et al., 2015).

\subsection{Evaluation of the Frequency of Barotrauma in Pacific Rockfishes}

All fish were collected from depths ranging from 13-40 meters (45-125 ft). The capture depth was recorded either via the reading from a fish finder (Humminbird Helix 5 Sonar G2 Fishfinder, Academy Sports and Outdoors) within 30 s of fish capture, or by recording the GPS coordinates of the location of capture (located within 5 minutes of capture) and then plotting coordinates using $\operatorname{ArcGIS}^{\circledR} 10.2$ (software by Esri ${ }^{\circledR}$, www.esri.com) and a bathymetry map provided by the Seafloor Mapping Lab of California State University, Monterey Bay (CSUMB, California Seafloor Mapping Project, 2018). The fish finder depth was primarily used for Deacon and Blue Rockfish 
since they are known to live above the seafloor. Since Gopher and Canary Rockfish are generally demersal species, the bottom depth was used as the measurement for capture depth (Hannah et al., 2011). If the depth could not be found using the fish finder or GPS coordinates, depth data was not used for that fish in analyses.

Every captured rockfish was identified to the species, measured (fork length), tagged with a T-bar anchor tag, and assessed for external symptoms of barotrauma. The following symptoms of barotrauma were recorded for each fish collected: everted esophageal tissue (EET), exophthalmia (EX), corneal (ocular) emphysema (CE), and anal protrusion (AP) (Table 1). All of these symptoms were measured categorically as either 'present' or 'absent.'

\subsection{Recapture of Tagged Fish to Assess Survivorship}

All captured fish were tagged so that recaptured fish could provide information on survival of fish that experienced barotrauma and survived days to years later. All T-bar tags have a unique ID and contain a phone number for reporting recaptured rockfish. Therefore, when a fish was recaptured, additional information such as the tag ID, species, date of recapture, and location of recapture was collected. With this information I was able to relate initial capture information (e.g., severity of barotrauma, depth of capture, location of capture) with recapture information (e.g., the fish's condition, date, and location of recapture). This data allowed me to determine if individuals survived after having barotrauma.

\subsection{Descending Device}

I selected the Barotrauma Reliever because it is a low-cost device that anglers can

make themselves and use with relative ease (Figure 2). The Barotrauma Reliever can also 
transport multiple fish at once, unlike some descending devices that are designed to transport only one or two fish at a time, such as the Shelton's Fish Descender, RokLees, and Blacktip Catch and Release (Oregon Department of Fish and Wildlife, 2019). To observe the response of recompression on rockfish, two GoPro cameras (GoPro Hero 3, GoPro, 3000 Clearview Way San Mateo, CA, USA 94402) were attached to the Barotrauma Reliever. The cameras were orientated to videotape footage of the descent and release of rockfish (Figure 2). One camera was angled up towards the fish to observe its response during descent, while the other camera was angled downward to observe the rockfish exiting the Barotrauma Reliever. A $50 \mathrm{~m}$ rope was attached to the top of the Barotrauma Reliever to manually lower the device and fish into the water. The rope was marked every meter, so the user could see the current depth of the Barotrauma Reliever. At the bottom of the device was a door that remained closed during descend to ensure fish were not released prematurely. Once the device reached the desired depth, the user pulled the rope upward to open the door and release the fish (Figure 2). Overall, this device is very simple and cheap, which may make it more desirable to use than other descending devices.

\subsection{Recompression}

Once fish were caught and processed (see Starr et al., 2015 for details), they were immediately placed in the descending device. Processing rarely took more than 5 minutes (Starr et al., 2015). If the descending device was in use, the rockfish were placed in an 70-liter seawater holding container until the device was available - fish were usually in the container for less than 5 minutes. Normally, one rockfish was descended at a time; however, up to three rockfish were descended at a time for some trials. 
The fish were placed in the Barotrauma Reliever and lowered to the fish's initial capture depth. This ensured fish experienced the same amount of pressure difference as they did during ascent (Hannah et al., 2011). Fish were descended at an average descent rate of about $20 \mathrm{~m} / \mathrm{min}$. Since the Barotrauma Reliever is weighted, it naturally sinks straight down. However, when there were high current drifts, the device sank at an angle. In those cases, the meter marks on the rope did not accurately represent the bottom depth because the device was sinking at an angle, rather than straight down. No data was used for fish in these conditions because the actual release depth was unknown. Additionally, I analyzed how well the Barotrauma Reliever preformed at descending, releasing, and recompressing fish. The device was considered to work properly if it transported and released fish at the desired depth.

Controlled descents were also conducted on rockfish not experiencing barotrauma. These fish experienced everything the fish with barotrauma did, the only difference being the controlled fish did not have any macroscopic signs of barotrauma. The controlled fish were handled and tagged to ensure the response of the fish upon release from the Barotrauma Reliever was dependent on the degree and stress of barotrauma, rather than the process of being descended, handled, or tagged. The controlled descents were performed to ensure my findings on behavioral responses to recompression were dependent on the fish experiencing barotrauma rather than the process of being descended in the Barotrauma Reliever. Sixty fish $(n=60)$ were descended as controls. Fifteen fish species (Canary, Gopher, Blue, and Deacon Rockfish) did not have barotrauma and were descended. 
Fish behavior was assessed during descent and upon release from the Barotrauma Reliever. The behavioral measures evaluated were: (1) the fish orienting itself vertically within the cage during descent, (2) the fish exiting the cage vertically, sideways, or upside down, (3) and the fish eventually swimming away from the descending device. Fish were rated on a presence or absence of behavior impairment (Table 2), which was converted to a binary scale: if the fish displayed a negative response from barotrauma it was given a score of 0 , whereas if the fish showed a recovery response from barotrauma it was given a score of 1 . A mean immediate composite behavioral score was then calculated for each species by adding the scores from each of the three parameters observed and dividing them by the sample size. Since there were three parameters, the range of the mean composite score was between 0 and 3, with lower scores indicating greater impairment, and higher scores representing less impairment.

\subsection{Analysis}

All data analysis was completed using JMP Pro 14 (SAS Institute Inc., North Carolina, USA). The mean frequency of barotrauma was calculated for each rockfish species as the total number of rockfish experiencing barotrauma divided by the total number captured. I then used the Wilcoxon each pair test to compare counts of macroscopic barotrauma among species. Each of the four macroscopic symptoms recorded - everted esophageal tissue (EET), exophthalmia (EX), corneal (ocular) emphysema (CE), and anal protrusion (AP) - were compared separately among species. Mean immediate composite behavioral scores by species were compared using Wilcoxon each pair test. 
To analyze how depth of capture influences barotrauma I used logistic regression models, likelihood ratios, and odds ratios. Tests and confidence intervals on odds ratios were likelihood ratio based. To analyze how likely rockfish species were to express symptoms of barotrauma in relation to depth, I used odds ratio. The odds ratio shows the estimated effect of capture depth on the odds of experiencing barotrauma. It is the same as the exponential slope estimate, but it also provides the lower and upper bounds for the estimated effect. The slope estimate for capture depth was exponentiated to be interpreted more easily. For example, the slope estimate for capture depth effect 0.1022 is exponentiated to 1.107. This means that for every meter increase in depth, the odds that a fish experiences barotrauma is multiplied by 1.107 (thus, increased by about $10 \%$ ). The nonparametric Kruskal-Wallis test was also used to determine whether the depth of capture was related to the presence or absence of macroscopic barotrauma symptoms (Sokal and Rohlf, 1981).

To examine the potential for a barotrauma depth threshold, I analyzed at what depth 50\% (BT50) of the fish displayed barotrauma (Blazer et al., 2016). The BT50 was found by running a one-way analysis between capture depth and barotrauma. Quantiles were then calculated to identify the depth at which $50 \%$ of fish experienced barotrauma. To further investigate if the BT50 was significant, I ran a Kruskal-Wallis test. This analysis showed if fish experiencing barotrauma were caught at or below the estimated depth threshold. To analyze relations between species and temperature change and size the Kruskal-Wallis test was used. I compared the controlled descends (fish without barotrauma) to fish having barotrauma by conducting a Kruskal-Wallis test to ensure fish 
were responding to having barotrauma rather than being processed, tagged, or descended.

I analyzed the efficacy of the Barotrauma Reliever by conducting a Fischer's exact test. 


\section{RESULTS}

\subsection{Incidences of Barotrauma Among Rockfish Species}

I analyzed the symptoms of barotrauma for four different species of rockfish. The capture depth ranged between 13-40 m, with most capture depths occurring between 24$30 \mathrm{~m}$ (Table 3). The frequency of fish experiencing barotrauma varied between species (Table 3; Fisher's exact test: $\mathrm{N}=1150, \mathrm{df}=3, \mathrm{r}^{2}=0.1213, \chi^{2}=163.55, \mathrm{P}<0.0001$ ). Fifty-six percent of Canary, $43 \%$ of Gopher, $35 \%$ of Deacon, and $11 \%$ of Blue Rockfish experienced barotrauma (Table 3).

The frequency of external symptoms of barotrauma varied among species (Table 5; Table 6). EET was the most common symptom of barotrauma in all species, $69 \%$ of Canary, $54 \%$ of Gopher, $90 \%$ of Deacon, and $66 \%$ of Blue Rockfish displayed EET as a symptom of barotrauma (Table 5). AP was the least common symptom in all species, $0 \%$ Canary, $10 \%$ of Gopher, $5 \%$ of Deacon, and $13 \%$ of Blue Rockfish displayed AP as a symptom of barotrauma (Table 5). Exophthalmia (EX) and corneal emphysema (CE) was displayed more in Canary and Gopher Rockfish than in Deacon and Blue Rockfish (Table $6)$.

\subsection{Incidences of Barotrauma Among Rockfish Species and Relationships to Depth of}

\section{Capture}

Depth was positively correlated with an increase in barotrauma for Blue Rockfish (Figure 3 and Table 4; $\mathrm{N}=555$, slope estimate $=0.160$, standard error $=0.026$, likelihood ratio $\chi^{2}=36.45, \mathrm{P}<0.0001$ ) and Gopher Rockfish (Figure 4 and Table 4, N=414, slope estimate $=0.102$, standard error $=0.021$; likelihood ratio $\left.\chi^{2}=23.88, \mathrm{P}<0.0001\right)$. However, 
this relationship was not significant for Canary (Table 4; $\mathrm{N}=62$, slope estimate $=0.003$, standard error $=0.067$, likelihood ratio $\chi^{2}=0.001, \mathrm{P}=0.9692$ ) or Deacon Rockfish (Table 4; $\mathrm{N}=119$, slope estimate $=0.079$, standard error $=0.048$, likelihood ratio $\chi^{2}=2.66, \mathrm{P}=0.1028$ ). The odds ratios showed the odds of Gopher Rockfish expressing barotrauma symptoms increases by a factor of 1.108 every meter. Therefore, the odds of a Gopher Rockfish having barotrauma increases by about $10 \%$ every meter (Table 4 ). The odds of a Blue Rockfish experiencing barotrauma increases by a factor of 1.173 , which means their odds of getting barotrauma increases by about $15 \%$ every meter (Table 4 ).

The presence of barotrauma symptoms in relation to depth varied between species (Fisher's exact test: $\mathrm{df}=3, \mathrm{P}<0.0001$ ). The presence of EET was positively correlated to capture depth in Gopher Rockfish (Table 5; Kruskal-Wallis test: $\mathrm{df}=1, \mathrm{P}<0.05$ ), Blue Rockfish (Table 5; Kruskal-Wallis test: $\mathrm{df}=1, \mathrm{P}<0.0001$ ), and Deacon Rockfish (Table 5; Kruskal-Wallis test: $\mathrm{df}=1, \mathrm{P}<0.05$ ), but not in Canary Rockfish (Table 5; Kruskal-Wallis test: $\mathrm{df}=1, \mathrm{P}>0.05)$.

I assessed the BT50 for each fish species, the depth when $50 \%$ of sampled fish exhibited barotrauma (Blazer et al., 2016). This technique allowed me to assess if a barotrauma depth threshold existed for each species (Table 3). Canary had a BT50 at 26 m, Gopher Rockfish had a BT50 at $27 \mathrm{~m}$, Deacon Rockfish had a BT50 at $25 \mathrm{~m}$, and Blue Rockfish had a BT50 at a depth of 29 m (Table 3). Gopher and Blue Rockfish were more likely to have barotrauma if they were catch deeper than their BT50, while Canary and Deacon Rockfish were not (Table 3). 


\subsection{Incidences of Barotrauma Among Rockfish Species in Relation to}

\section{Temperature and Fish Size}

There was a difference in average seafloor-surface temperature differential experienced among species (ANOVA: $\mathrm{df}=3, \mathrm{~F}=5.0851, \mathrm{P}=0.0017$ ). Canary Rockfish (Kruskal-Wallis test: $\mathrm{N}=62, \mathrm{df}=1, \chi^{2}=5.535, \mathrm{Z}=-2.345, \mathrm{P}=0.0186$ ) were more likely to have barotrauma when there was a larger temperature change from the bottom to the surface. However, this relationship between temperature change and barotrauma was not observed in Blue Rockfish (Kruskal-Wallis test: $\mathrm{N}=555, \mathrm{df}=1, \chi^{2}=4.899, \mathrm{Z}=2.213$, $\mathrm{P}=0.0569$ ), Deacon Rockfish (Kruskal-Wallis test: $\mathrm{N}=119, \mathrm{df}=1, \chi^{2}=0.144, \mathrm{Z}=-0.377$, $\mathrm{P}=0.7043$ ) or Gopher Rockfish (Kruskal-Wallis test: $\mathrm{N}=414, \mathrm{df}=1, \chi^{2}=1.539, \mathrm{Z}=1.240$, $\mathrm{P}=0.2148$ ). Size was not a significant predictor in fish displaying external symptoms of barotrauma (Kruskal-Wallis test: $\mathrm{N}=1145, \mathrm{df}=1, \chi^{2}=0.865, \mathrm{Z}=0.929, \mathrm{P}=0.3523$ ).

\subsection{Behavior of Fish Following Release}

Rockfish species differed in the ways in which behavior was influenced by barotrauma (Table 7; Table 8; Kruskal-Wallis test: $\mathrm{N}=191, \mathrm{df}=3, \chi^{2}=21.4387, \mathrm{P}<0.0001$ ). Forty-nine percent of Canary Rockfish, 60\% of Gopher Rockfish, 53\% of Deacon Rockfish, and 43\% of Blue Rockfish swam away from the Barotrauma Reliever upon release (Table 7). The mean immediate behavioral composite scores were different among species ANOVA: $\mathrm{df}=3, \mathrm{SS}=28.57, \mathrm{~F}=7.88, \mathrm{P}<0.0001)$. Canary Rockfish had a mean immediate behavioral composite score of 1.76 , Gopher Rockfish a score of had 2.54, Deacon Rockfish had a score of 1.74, and Blue Rockfish had a score of 1.79 (Table 7). Gopher Rockfish were the least impaired by barotrauma compared to the other 
rockfish (Table 7; Table 8). Proportions of barotrauma symptoms persisting after being descended to depth were 0.17 for EET, 0.43 for EX, 0.11 for CE, and 0.29 for AP.

\subsection{Survival of Fish Following Release}

Over an eight-year time period, CCFRP recaptured 20 rockfish that displayed barotrauma when initially captured (Table 9). It is unknown if these fish were recompressed since CCFRP was not recording recompression data during this time. However, this data shows that some rockfish can survive long-term from barotrauma. The species recaptured were initially caught at various depths (20-27 m). Species recaptured were Black Rockfish (Sebastes melanops), Copper Rockfish (Sebastes caurinus), Kelp Rockfish (Sebastes atrovirens), as well as Blue Rockfish and Gopher Rockfish. All Gopher Rockfish $(\mathrm{N}=10)$, that initially exhibited signs of EET or CE were recaptured (Table 9). Black Rockfish and Blue Rockfish initially exhibiting AP and tight abdomen were also recaptured (Table 9). No species initially exhibiting EX were recaptured, however it is unknown if this symptom was being recorded before 2014 (Table 9). Therefore, while some fish could have exhibited EX, researchers recording data were not assessing for EX.

\subsection{Recompression System Effectiveness}

I tested the efficacy of the Barotrauma Reliever to analyze how successful it was at descending and releasing fish at a specific depth. It was considered successful if it sank straight down, the door opened when triggered, and the fish were released from the device. The Barotrauma Reliever was considered unsuccessful if the door did not open, opened too early or too late, or if a fish was stuck in one of the square holes on the exterior of the device. Eight-four percent of the time the Barotrauma Reliever correctly 
transported and released fish to the desired depth (Fisher's exact test: $\mathrm{N}=223, \mathrm{df}=3$, $\left.\mathrm{r}^{2}=0.0733, \mathrm{P}=0.0024\right)$. Forty-three percent of descended fish did not show symptoms of barotrauma upon release and swam out of the Barotrauma Reliever successfully (Table 10). While $15 \%$ of descended fish still exhibited symptoms of barotrauma upon release and did not swim out of the Barotrauma Reliever successfully (Table 10). I compared the controlled descends (fish without barotrauma) to fish having barotrauma by conducting a Kruskal-Wallis test. Controlled fish had higher mean composite scores compared to fish with barotrauma (Kruskal-Wallis test: $\mathrm{df}=1, \chi^{2}=75.188, \mathrm{P}<0.0001$ ). 


\section{DISCUSSION}

The frequency of external symptoms of barotrauma varied among species. Other studies have seen diverse species responding to barotrauma differently as well (Hannah et al., 2007; Hannah et al., 2011; Hannah and Matteson, 2007; Jarvis and Lowe, 2008; Pribyl et al., 2011, Rodgveller et al., 2017). Symptoms of barotrauma in Canary Rockfish were similar in other studies, where the most common symptoms were EX and EET (Pribyl et al., 2011; Hannah et al., 2008). Blue and Deacon Rockfish expressed different rates for all barotrauma symptoms, even though they are phylogenetically related (Frable et al., 2015). This suggests that life history and phylogenetic relatedness do not always accurately predict how rockfish will respond to barotrauma (Pribyl et al., 2011).

When I combined data from all species, the capture depth was related to frequency of barotrauma. When I separated the species, barotrauma was positively correlated with depth in only Blue Rockfish and Gopher Rockfish (Figure 3; Figure 4; Table 4). The presence of macroscopic barotrauma signs was positively correlated to capture depth in other studies as well (Pribyl et al., 2011; Jarvis and Lowe, 2008; Curtis et al., 2015). However, this relationship was not observed in Canary Rockfish or Deacon Rockfish (Table 4). Other studies also did not observe this correlation in Canary Rockfish (Hannah and Matteson, 2007; Pribyl et al., 2011). It is interesting that Blue Rockfish and Deacon Rockfish did not display similar results in relation to depth of capture and expressions of barotrauma since they are sister species. I think the depth range sampled was too narrow to observe this trend in Deacon Rockfish. Hannah et al., 2008 found that external signs of barotrauma increased in frequency with capture in Deacon Rockfish. 
However, their depth ranges were between 10-51 meters (Hannah et al., 2008), whereas most Deacon Rockfish sampled in my study were between 25-35 m, (Table 3). Therefore, it appears capture depth does influence frequency of barotrauma, but deeper depths may need to be sampled to see this correlation in some species.

Canary Rockfish were more likely to have barotrauma when experiencing a greater temperature change from the bottom to the surface. The average temperature difference between the bottom and surface temperature was $2^{\circ} \mathrm{C}$. Other studies have shown that larger temperature differences increase the incidence of barotrauma in Pacific rockfishes (Jarvis and Lowe 2008; Hannah et al., 2011). Gases expand more in warmer temperatures, which may lead to a higher susceptibility to barotrauma (Pribyl et al., 2009). Therefore, barotrauma injuries could be more severe in areas with strong thermoclines. Increased temperature differentials between capture depth and the surface may also increase discard mortality (Davis, 2002). Canary Rockfish may have been the only species to show a correlation between temperature difference and barotrauma because they were caught at deeper depths with colder temperatures. Therefore, Canary Rockfish experienced the largest temperature change compared to the other species.

The size of the fish did not affect the presence of barotrauma or immediate behavior after recompression in my study. Other studies have not seen a correlation between fish size and incidents of barotrauma or on short-term survive after recompression (Sumpton et al., 2010; Gitschlag and Renaud 1994; Collins et al., 1999; Jarvis and Lowe, 2008; Hannah et al. 2011). Additionally, CCFRP uses typical hook-andline fishing gear in the recreational fishery, which may mean that barotrauma is less likely to occur in small fish because they rarely get caught on the bigger hooks. 
Observations of release behavior at depth was effective for identifying rockfish with immediate behavioral impairment after capture. To ensure behavioral impairment was due to barotrauma injuries instead of being processed and descended, controlled rockfish without barotrauma injuries were also descended using the Barotrauma Reliever. Controlled rockfish that did not have barotrauma and were caught at similar depths as those with barotrauma, did not show behavioral impairment. Therefore, rockfish are behavioral impaired from the injuries of barotrauma, rather than being descended in the Barotrauma Reliever. Behavioral scores revealed differences between rockfish species in how effective recompression was at alleviating immediate behavioral impairments caused by barotrauma. When analyzing the video data of rockfish being descended via the Barotrauma Reliever, Gopher Rockfish were the least behavioral impaired after recompression. Behavioral impairment at release has been linked to predicting mortality in some species of fish (Davis 2005; Davis and Ottmar 2006, Rodgveller et al., 2017). Davis and Ottmar (2006) found loss of vertical orientation was a good indicator in subsequent mortality in Walleye Pollock (Theragra chalcogramma), Sablefish (Anoplopoma fimbria), Northern Rock Sole (Lepidopsetta polyxystra), and Pacific Halibut (Hippoglossus stenolepis). Therefore, Gopher Rockfish may have the lowest delayed mortality from barotrauma compared to Canary, Blue, and Deacon Rockfish.

It is unclear how long it takes barotrauma symptoms and behavioral impairments to be alleviated. I observed some symptoms dissipate during recompression, therefore some signs of barotrauma can subside within seconds of recompression. While, other signs of barotrauma persisted even after recompression. Based on my video data, I 
observed everted esophageal tissue dissipate the most, while exophthalmia persisted the most.

Recovery from barotrauma can take hours to days, even with recompression (Rogers et al., 2001, Rodgveller et al., 2017). Sixty-nine of all the fish I recompressed did not display symptoms of barotrauma after recompression. After 2 days of recompression, Jarvis and Lowe (2008) saw less than 1\% of rockfish still displaying barotrauma signs. Therefore, recompression appears to help decrease barotrauma symptoms (Hannah and Matteson, 2007; Hannah et al, 2011; Hochhalter and Reed, 2011; Jarvis and Lowe, 2008; Parker et al. 2006).

Rockfish can be behaviorally impaired from barotrauma even after they are recompressed (Jarvis and Lowe, 2008; Hannah et al. 2011, Rodgveller et al., 2017). For example, $26 \%$ of recompressed rockfish did not show external signs of barotrauma but did not swim away from the Barotrauma Reliever, instead they appeared stunned and drifted out of view from the camera. Some symptoms of barotrauma can have longer lasting effects (Rogers et al., 2011; Davis, 2005) than other symptoms. For example, corneal emphysema was shown to negatively affect the vision of Rosy Rockfish (Sebastes rosaceus) a month after recompression (Rogers et al., 2011). Thus, the $31 \%$ of rockfish that still exhibited signs of barotrauma in my study may have needed more time for the symptoms to dissipate.

Recompressing fish has been shown to increase short-term survival (Curtis et al., 2015; Hannah et al., 2012; Jarvis and Lowe 2008, Rodgveller et al., 2017). Red snapper (Lutjanus campechanus) were more likely to survive barotrauma within a 72-hour period after release when recompressed to compared to vented surface release and nonvented 
surface release (Curtis et al., 2015). Hannah et al., 2012 observed 78\% of Blue Rockfish and $100 \%$ of Canary Rockfish were alive 41-71 hours after recompression from barotrauma. Jarvis and Lowe (2008) found post recompression survival to be speciesspecific for rockfishes, with only 36\% of Squarespot Rockfish (Sebastes hopkinsi) surviving 2 days after recompression from barotrauma, while $82 \%$ of Starry Rockfish (Sebastes constellatus) survived. This information further supports that rockfish species respond differently to recompression following barotrauma.

Two hundred thirty-nine rockfish were recaptured at depths between 18-33 m, between the years 2007 and 2015. The recaptured rockfish were of various species, with some exhibiting signs of barotrauma. Twenty of the 239 recaptures initially had barotrauma when they were first caught. The recapture rate of all tagged rockfish was $0.437 \%$, and the recapture rate of rockfish with barotrauma was $0.037 \%$. The recapture rates are expected to be low due to the sampling protocol of CCFRP (Starr et al., 2015). The 20 recaptured rockfish that initially had barotrauma lived between 22 days and 3 years after having barotrauma (Table 10). This data shows that rockfish having barotrauma injuries are recaptured at a lower rate than rockfish not experiencing barotrauma. It is unknown if these rockfish were descended or not because it is not a required protocol for CCFRP. However, it does suggest rockfish can survive long term after experiencing barotrauma. Other studies have observed increased survivorship of fish experiencing barotrauma when they are recompressed (Hochhalter and Reed, 2011; Jarvis and Lowe, 2008; Parker et al. 2006). A seventeen-day mark and recapture study analyzing the effectiveness of deep water release on Yelloweye Rockfish showed 98\% survived after deep depth release, while only $22 \%$ survived when released at the surface 
(Hochhalter and Reed, 2011). Ninety-seven percent of Black Rockfish (Sebastes

melanops) survived 21 days after experiencing barotrauma when they were recompressed in a pressure chamber (Parker et al., 2006). Jarvis and Lowe 2008 reported 3\% of rockfish initially having barotrauma were recaptured after deep depth release. Days at liberty for the recaptured fish was between 14-447 days (Jarvis and Lowe, 2008). All of this data further suggests rockfish can survive long-term after barotrauma if released at depth.

This information is pertinent for management implications because rockfish are not required to be descended. Thus, some anglers release unwanted fish at the surface because it is easiest, fastest, and cheapest (Hazell et al., 2016). This is an issue because rockfish are less likely to survive if they have barotrauma and are released at the surface (Hannah et al., 2008b; Hochhalter and Reed, 2011; Jarvis and Lowe, 2008; Parker et al. 2006). One study found $70 \%$ of Canary Rockfish and $68 \%$ of Blue Rockfish were unable to submerge themselves at the surface within 5 minutes when caught between $30-51 \mathrm{~m}$ (Hannah et al., 2008b). Therefore, a recompression device was properly used to recompress undesired fish it could help increase the survivorship of fish having barotrauma (Hannah and Matteson, 2007; Hannah et al, 2011; Hochhalter and Reed, 2011; Jarvis and Lowe, 2008; Parker et al. 2006).

The Barotrauma Reliever is an effective device — successfully transporting and releasing fish at a desired depth $84 \%$ of the time. Additionally, $69 \%$ rockfish were recompressed and did not exhibit any signs of barotrauma upon release. However, the device was unsuccessful in strong currents because it sank at an angle and usually did not reach the seafloor. It was also faulty when a small fish became stuck in one of the square 
holes on the exterior of the crate because the fish could not swim out. These issues occurred $16 \%$ of the time. Simple adjustments such as decreasing the diameter of the holes on the crate would allow fish of all sizes to be descended. Adding weights during strong currents would correct the Barotrauma Reliever from drifting at an angle. With more testing and design improvements, the Barotrauma Reliever could become more effective.

Other descending devices are available to recompress fish as well. Hazell et al. (2016) analyzed the effectivity of several different descending devices for multiple species in the Mid-Atlantic and found that $64 \%$ of the devices were successful. Most importantly, 93\% of anglers said they would support captains using descending devices (Hazell et al., 2016). However, in order to get support from all anglers, incentives such as extended fishing seasons or bag limits for captains regularly using descending devices were suggested by Sea Grant (Hazell et al., 2016). Therefore, using the Barotrauma Reliever is a practical technique in decreasing discard mortality. With the successes of the Barotrauma Reliever, it is economically and ecologically important to further investigate and implement techniques to decrease discard mortality in rockfish. This work adds to the growing body of literature that suggests the need to recompress undesirable fish. This area of research needs more attention, especially since recompressing fish can potentially decrease discard mortality. Therefore, some fisheries could benefit from requiring undesirable fish to be descended. Descending fish gives the organism the opportunity to survive and reproduce, in turn creating more offspring to support the fishery. Continued research on recompression will help our understanding on how well fish survive after recompression. 


\section{TABLES}

Table 1. Abbreviations and Descriptions of Observed Barotrauma Symptoms.

\begin{tabular}{|l|c|l|}
\hline \multicolumn{1}{|c|}{ Barotrauma Symptoms } & Abbreviated Symptoms & \multicolumn{1}{|c|}{ Description of Symptoms } \\
\hline $\begin{array}{l}\text { Everted esophageal tissue } \\
\text { (stomach in mouth) }\end{array}$ & EET & $\begin{array}{l}\text { Esophageal tissue protruding } \\
\text { into mouth }\end{array}$ \\
\hline Exophthalmia (pop-eye) & EX & Eyes protruding outwards \\
\hline $\begin{array}{l}\text { Corneal (ocular) } \\
\text { emphysema }\end{array}$ & CE & Gas visible in eye membrane \\
\hline Anal protrusion & AP & $\begin{array}{l}\text { Anal gland protruding out of } \\
\text { vent }\end{array}$ \\
\hline
\end{tabular}


Table 2. Scoring System for Mean Immediate Behavioral Composite Scores. Lower mean composite scores indicate more behavioral impairment, while higher scores indicate less impairment from barotrauma.

\begin{tabular}{|l|c|}
\hline \multicolumn{1}{|c|}{ Assessments } & Score \\
\hline $\begin{array}{l}\text { Was the fish able to orient itself vertically within the cage during } \\
\text { descent? }\end{array}$ & 1 or 0 \\
\hline Did the fish exit the cage vertical (1), sideways (0), or upside down (0)? & 1 or 0 \\
\hline Did the fish swim away from the cage? & 1 or 0 \\
\hline \hline Mean immediate behavioral composite score range & $0-3$ \\
\hline
\end{tabular}


Table 3. Frequency of Four Species of Pacific Rockfish Displaying Barotrauma. Number of fish sampled $(\mathrm{N})$, average total length, and average depth of capture used in the study; values in parentheses are ranges are shown. Depth thresholds (BT50) are when $50 \%$ of the sample exhibited barotrauma. A one-way analysis displaying quantiles displayed the depth when $50 \%$ of the sample had barotrauma (Kruskal-Wallis: $\mathrm{df}=1$, $\alpha=0.05$ ).

\begin{tabular}{|l|c|c|c|c|c|c|c|}
\hline Species & $\mathrm{N}$ & $\begin{array}{c}\text { Total length } \\
(\mathrm{cm})\end{array}$ & $\begin{array}{c}\text { Depth of } \\
\text { capture (m) }\end{array}$ & $\begin{array}{c}\text { Barotrauma } \\
\text { Frequency }\end{array}$ & BT50 (m) & $\begin{array}{c}\mathrm{Z} \text { (test } \\
\text { statistic) }\end{array}$ & P-value \\
\hline $\begin{array}{l}\text { Canary } \\
\text { Rockfish }\end{array}$ & 62 & $28.2(13-39)$ & $30.4(23-38)$ & $56 \%$ & 26 & -0.057 & 0.9489 \\
\hline $\begin{array}{l}\text { Gopher } \\
\text { Rockfish }\end{array}$ & 414 & $27.5(16-34)$ & $25.9(15-38)$ & $43 \%$ & 27 & 5.066 & $<0.0001$ \\
\hline $\begin{array}{l}\text { Deacon } \\
\text { Rockfish }\end{array}$ & 119 & $28.7(16-55)$ & $28.8(18-37)$ & $35 \%$ & 25 & 1.794 & 0.0723 \\
\hline $\begin{array}{l}\text { Blue } \\
\text { Rockfish }\end{array}$ & 555 & $27.6(7-40)$ & $24.2(15-37)$ & $11 \%$ & 29 & 6.159 & $<0.0001$ \\
\hline
\end{tabular}


Table 4. Output of Logistic Regression Analysis of the Proportion of Pacific Rockfishes Displaying Symptoms of Barotrauma in Relation to Capture Depth by Species.

\begin{tabular}{|l|c|c|c|c|c|c|c|}
\hline \multicolumn{1}{|c|}{ Species } & $\mathrm{N}$ & $\begin{array}{c}\text { Independent } \\
\text { Variable }\end{array}$ & $\begin{array}{c}\text { Slope } \\
\text { Estimate }\end{array}$ & $\mathrm{SE}$ & $\begin{array}{c}\text { Likelihood } \\
\text { ratio } \chi^{2}\end{array}$ & $\begin{array}{c}\text { Odds } \\
\text { Ratio }\end{array}$ & P-value \\
\hline $\begin{array}{l}\text { Canary } \\
\text { Rockfish }\end{array}$ & 62 & $\begin{array}{c}\text { Constant } \\
\text { Depth }\end{array}$ & 0.003 & 0.067 & 0.001 & 1.003 & 0.9692 \\
\hline $\begin{array}{l}\text { Gopher } \\
\text { Rockfish }\end{array}$ & 414 & $\begin{array}{c}\text { Constant } \\
\text { Depth }\end{array}$ & 0.102 & 0.021 & 23.88 & 1.108 & $<0.0001$ \\
\hline $\begin{array}{l}\text { Deacon } \\
\text { Rockfish }\end{array}$ & 119 & $\begin{array}{c}\text { Constant } \\
\text { Depth }\end{array}$ & 0.079 & 0.048 & 2.66 & 1.082 & 0.1028 \\
\hline $\begin{array}{l}\text { Blue } \\
\text { Rockfish }\end{array}$ & 555 & $\begin{array}{c}\text { Constant } \\
\text { Depth }\end{array}$ & 0.160 & 0.026 & 36.45 & 1.173 & $<0.0001$ \\
\hline
\end{tabular}


Table 5. Summary of Kruskal-Wallis Test. These results determine whether the depth of capture was related to the presence or absence of macroscopic barotrauma indicators. $\mathrm{Z}=$ the $\mathrm{Z}$-statistic from the normal distribution. $\mathrm{NA}=$ not applicable due to fish not showing any signs of specified barotrauma indicator.

\begin{tabular}{|llllllll|}
\hline Indicator & Species & $\mathrm{N}$ & $\begin{array}{l}\text { Proportion } \\
\text { expressing } \\
\text { symptom }\end{array}$ & $\chi^{2}$ & $\mathrm{Z}$ & $\mathrm{df}$ & P-value \\
\hline EET & Canary & 34 & 0.69 & 0.142 & -0.369 & 1 & 0.7062 \\
& Gopher & 171 & 0.54 & 7.152 & 2.674 & 1 & 0.0075 \\
& Deacon & 41 & 0.90 & 7.409 & 2.719 & 1 & 0.0065 \\
& Blue & 69 & 0.66 & 34.514 & 5.874 & 1 & $<0.000$ \\
EX & Canary & 34 & 0.31 & 0.317 & 0.555 & 1 & 0.579 \\
& Gopher & 171 & 0.26 & 8.392 & 2.896 & 1 & 0.0038 \\
& Deacon & 41 & 0 & NA & NA & NA & NA \\
& Blue & 69 & 0.09 & 1.090 & 1.042 & 1 & 0.2964 \\
CE & Canary & 34 & 0.14 & 6.998 & 2.632 & 1 & 0.0085 \\
& Gopher & 171 & 0.23 & 10.137 & 3.183 & 1 & 0.0015 \\
& Deacon & 41 & 0.1 & 0.902 & 0.935 & 1 & 0.3422 \\
& Blue & 69 & 0.05 & 0.747 & 0.863 & 1 & 0.3872 \\
AP & Canary & 34 & 0 & NA & NA & NA & NA \\
& Gopher & 171 & 0.10 & 1.200 & 1.094 & 1 & 0.2733 \\
& Deacon & 41 & 0.12 & 4.993 & -2.224 & 1 & 0.0255 \\
& Blue & 69 & 0.17 & 0.285 & 0.533 & 1 & 0.5931 \\
\hline
\end{tabular}


Table 6. Summary of Wilcoxon Each Pair Test. These results show differences in barotrauma symptoms between species. Bonferroni correction applied; $\alpha=0.0083$.

\begin{tabular}{|c|c|c|c|c|c|c|}
\hline Indicator & Species & Species & $\begin{array}{c}\text { Score mean } \\
\text { difference }\end{array}$ & $\begin{array}{c}\mathrm{SE} \\
\text { difference }\end{array}$ & $\begin{array}{c}\mathrm{Z} \text { (test } \\
\text { statistic) }\end{array}$ & $\mathrm{P}$-value \\
\hline \multirow[t]{6}{*}{ EET } & Canary Rockfish & Blue Rockfish & 97.17 & 12.60 & 7.708 & $<0.0001$ \\
\hline & Deacon Rockfish & Blue Rockfish & 83.32 & 10.89 & 7.644 & $<0.0001$ \\
\hline & Gopher Rockfish & Blue Rockfish & 77.42 & 10.93 & 7.080 & $<0.0001$ \\
\hline & Deacon Rockfish & Gopher Rockfish & 23.29 & 12.03 & 1.935 & 0.0529 \\
\hline & Deacon Rockfish & Canary Rockfish & -6.12 & 6.74 & -0.907 & 0.3642 \\
\hline & Gopher Rockfish & Canary Rockfish & -36.93 & 14.08 & -2.621 & 0.0088 \\
\hline Indicator & Species & Species & $\begin{array}{l}\text { Score mean } \\
\text { difference }\end{array}$ & $\begin{array}{c}\text { SE } \\
\text { difference }\end{array}$ & $\begin{array}{c}\mathrm{Z} \text { (test } \\
\text { statistic) }\end{array}$ & $\mathrm{P}$-value \\
\hline \multirow[t]{6}{*}{ EX } & Canary Rockfish & Blue Rockfish & 53.61 & 5.93 & 9.029 & $<0.0001$ \\
\hline & Gopher Rockfish & Blue Rockfish & 52.08 & 6.83 & 7.625 & $<0.0001$ \\
\hline & Deacon Rockfish & Blue Rockfish & -1.20 & 1.83 & -0.652 & 0.5140 \\
\hline & Gopher Rockfish & Canary Rockfish & -15.77 & 10.53 & -1.497 & 01343 \\
\hline & Deacon Rockfish & Canary Rockfish & 16.04 & 3.39 & -4.724 & $<0.0001$ \\
\hline & Deacon Rockfish & Gopher Rockfish & -29.60 & 7.79 & -3.799 & 0.0001 \\
\hline Indicator & Species & Species & $\begin{array}{l}\text { Score mean } \\
\text { difference }\end{array}$ & $\begin{array}{c}\text { SE } \\
\text { difference }\end{array}$ & $\begin{array}{c}\mathrm{Z} \text { (test } \\
\text { statistic) }\end{array}$ & $\mathrm{P}$-value \\
\hline \multirow[t]{6}{*}{$\mathrm{CE}$} & Gopher Rockfish & Blue Rockfish & 44.19 & 6.48 & 6.816 & $<0.0001$ \\
\hline & Canary Rockfish & Blue Rockfish & 23.20 & 4.68 & 4.960 & $<0.0001$ \\
\hline & Gopher Rockfish & Canary Rockfish & 3.79 & 9.49 & 0.399 & 0.6895 \\
\hline & Deacon Rockfish & Blue Rockfish & 1.01 & 2.61 & 0.384 & 0.7009 \\
\hline & Deacon Rockfish & Canary Rockfish & -6.52 & 2.54 & -2.564 & 0.0103 \\
\hline & Deacon Rockfish & Gopher Rockfish & -23.50 & 7.39 & -3.179 & 0.0015 \\
\hline Indicator & Species & Species & $\begin{array}{l}\text { Score mean } \\
\text { difference }\end{array}$ & $\begin{array}{c}\text { SE } \\
\text { difference }\end{array}$ & $\begin{array}{c}\mathrm{Z} \text { (test } \\
\text { statistic) }\end{array}$ & $\mathrm{P}$-value \\
\hline \multirow[t]{6}{*}{ AP } & Gopher Rockfish & Blue Rockfish & 12.90 & 4.99 & 2.586 & 0.0097 \\
\hline & Gopher Rockfish & Canary Rockfish & 9.76 & 6.02 & 1.621 & 0.1049 \\
\hline & Deacon Rockfish & Canary Rockfish & 1.50 & 1.48 & 1.015 & 0.3099 \\
\hline & Deacon Rockfish & Blue Rockfish & 0.80 & 4.11 & 0.194 & 0.8458 \\
\hline & Canary Rockfish & Blue Rockfish & -4.43 & 4.67 & -0.948 & 0.3427 \\
\hline & Deacon Rockfish & Gopher Rockfish & -6.45 & 5.14 & -1.255 & 0.2093 \\
\hline
\end{tabular}


Table 7. Proportions of Mean Immediate Behavioral Composite Scores for Canary, Gopher, Deacon, and Blue Rockfish. Lower mean composite scores indicate more behavioral impairment, while higher scores indicate less impairment from barotrauma.

\begin{tabular}{|l|c|c|c|c|c|}
\hline \multicolumn{1}{|c|}{ Species } & $\mathrm{N}$ & $\begin{array}{c}\text { Proportions of } \\
\text { fish vertical in } \\
\text { the cage during } \\
\text { descent }\end{array}$ & $\begin{array}{c}\text { Proportions of } \\
\text { fish exiting } \\
\text { the cage } \\
\text { vertically }\end{array}$ & $\begin{array}{c}\text { Proportions of } \\
\text { fish swimming } \\
\text { away from the } \\
\text { cage }\end{array}$ & $\begin{array}{c}\text { Mean } \\
\text { Composite } \\
\text { Score }\end{array}$ \\
\hline $\begin{array}{l}\text { Canary } \\
\text { Rockfish }\end{array}$ & 28 & 0.46 & 0.43 & 0.49 & $\mathbf{1 . 7 6}$ \\
\hline $\begin{array}{l}\text { Gopher } \\
\text { Rockfish }\end{array}$ & 130 & 0.57 & 0.77 & 0.60 & $\mathbf{2 . 5 4}$ \\
\hline $\begin{array}{l}\text { Deacon } \\
\text { Rockfish }\end{array}$ & 17 & 0.35 & 0.40 & 0.53 & $\mathbf{1 . 7 4}$ \\
\hline $\begin{array}{l}\text { Blue } \\
\text { Rockfish }\end{array}$ & 16 & 0.42 & 0.60 & 0.43 & $\mathbf{1 . 7 9}$ \\
\hline
\end{tabular}


Table 8. Summary of Wilcoxon Each Pair Test Results from the Mean Immediate Composite Scores in Table 7. Bonferroni correction applied; $\alpha=0.0083$.

\begin{tabular}{|l|l|c|c|c|c|}
\hline \multicolumn{1}{|c|}{ Species } & \multicolumn{1}{|c|}{ Species } & $\begin{array}{c}\text { Score mean } \\
\text { difference }\end{array}$ & $\begin{array}{c}\text { Standard } \\
\text { error } \\
\text { difference }\end{array}$ & $\begin{array}{c}\text { Z (test } \\
\text { statistic) }\end{array}$ & P-value \\
\hline $\begin{array}{l}\text { Gopher } \\
\text { Rockfish }\end{array}$ & $\begin{array}{l}\text { Canary } \\
\text { Rockfish }\end{array}$ & 34.78 & 10.21 & 3.405 & 0.0007 \\
\hline $\begin{array}{l}\text { Gopher } \\
\text { Rockfish }\end{array}$ & $\begin{array}{l}\text { Blue } \\
\text { Rockfish }\end{array}$ & 31.00 & 12.03 & 2.577 & 0.0100 \\
\hline $\begin{array}{l}\text { Canary } \\
\text { Rockfish }\end{array}$ & $\begin{array}{l}\text { Blue } \\
\text { Rockfish }\end{array}$ & 1.23 & 3.83 & 0.321 & 0.7484 \\
\hline $\begin{array}{l}\text { Deacon } \\
\text { Rockfish }\end{array}$ & $\begin{array}{l}\text { Blue } \\
\text { Rockfish }\end{array}$ & 1.19 & 3.23 & 0.369 & 0.7122 \\
\hline $\begin{array}{l}\text { Deacon } \\
\text { Rockfish }\end{array}$ & $\begin{array}{l}\text { Canary } \\
\text { Rockfish }\end{array}$ & -0.17 & 3.91 & -0.043 & 0.9654 \\
\hline $\begin{array}{l}\text { Deacon } \\
\text { Rockfish }\end{array}$ & $\begin{array}{l}\text { Gopher } \\
\text { Rockfish }\end{array}$ & -34.00 & 11.83 & -2.874 & 0.0040 \\
\hline
\end{tabular}


Table 9. Total Recaptured Pacific Rockfish Displaying Barotrauma and Exhibiting Long-term Survival. UN=Unknown.

\begin{tabular}{|c|c|c|c|}
\hline Species & $\begin{array}{l}\text { Barotrauma } \\
\text { Symptoms }\end{array}$ & $\begin{array}{c}\text { Liberty at Sea } \\
\text { (days) }\end{array}$ & Capture Depth (m) \\
\hline Black Rockfish & $\mathrm{CE}$ & 559 & 25 \\
\hline Blue Rockfish & AP & 533 & 28 \\
\hline Blue Rockfish & Tight abdomen & 315 & 29 \\
\hline Copper Rockfish & $\mathrm{CE}$ & 30 & UN \\
\hline Copper Rockfish & AP & 414 & UN \\
\hline Copper Rockfish & AP & 1,095 & 18 \\
\hline Gopher Rockfish & EET & 1,095 & 25 \\
\hline Gopher Rockfish & $\mathrm{CE}$ & 1,095 & 25 \\
\hline Gopher Rockfish & $\mathrm{CE}$ & 730 & 33 \\
\hline Gopher Rockfish & $\mathrm{CE}$ & 110 & 19 \\
\hline Gopher Rockfish & $\mathrm{CE}$ & 705 & 23 \\
\hline Gopher Rockfish & $\mathrm{CE}$ & 781 & 26 \\
\hline Gopher Rockfish & EET & 584 & UN \\
\hline Gopher Rockfish & EET & 472 & 26 \\
\hline Gopher Rockfish & EET & 22 & 21 \\
\hline Gopher Rockfish & $\mathrm{CE}$ & 525 & 22 \\
\hline Gopher Rockfish & EET & 680 & 28 \\
\hline Gopher Rockfish & EET & 728 & 31 \\
\hline Kelp Rockfish & AP & 390 & 26 \\
\hline Kelp Rockfish & AP & 730 & 21 \\
\hline
\end{tabular}


Table 10. Proportions of Rockfish Displaying Barotrauma Symptoms and Swimming Behavior After Recompression. No barotrauma symptoms mean no signs of barotrauma were visible upon release, while "Barotrauma Symptoms" mean there were visible signs of barotrauma after release (Fisher's exact test: $\mathrm{df}=1$, $\left.\mathrm{r}^{2}=0.6035, \chi^{2}=156.729, \mathrm{P}<0.0001\right)$.

\begin{tabular}{|c|c|c|c|c|c|}
\hline Species & $\mathrm{N}$ & $\begin{array}{c}\text { No Barotrauma } \\
\text { Symptoms and } \\
\text { Swam Away }\end{array}$ & $\begin{array}{c}\text { No Barotrauma } \\
\text { Symptoms and } \\
\text { Didn't Swim } \\
\text { Away }\end{array}$ & $\begin{array}{c}\text { Barotrauma } \\
\text { Symptoms } \\
\text { and Swim } \\
\text { Away }\end{array}$ & $\begin{array}{c}\text { Barotrauma } \\
\text { Symptoms and } \\
\text { Didn't Swim } \\
\text { Away }\end{array}$ \\
\hline $\begin{array}{c}\text { All } \\
\text { Rockfish }\end{array}$ & 191 & 0.43 & 0.26 & 0.16 & 0.15 \\
\hline
\end{tabular}




\section{FIGURES}

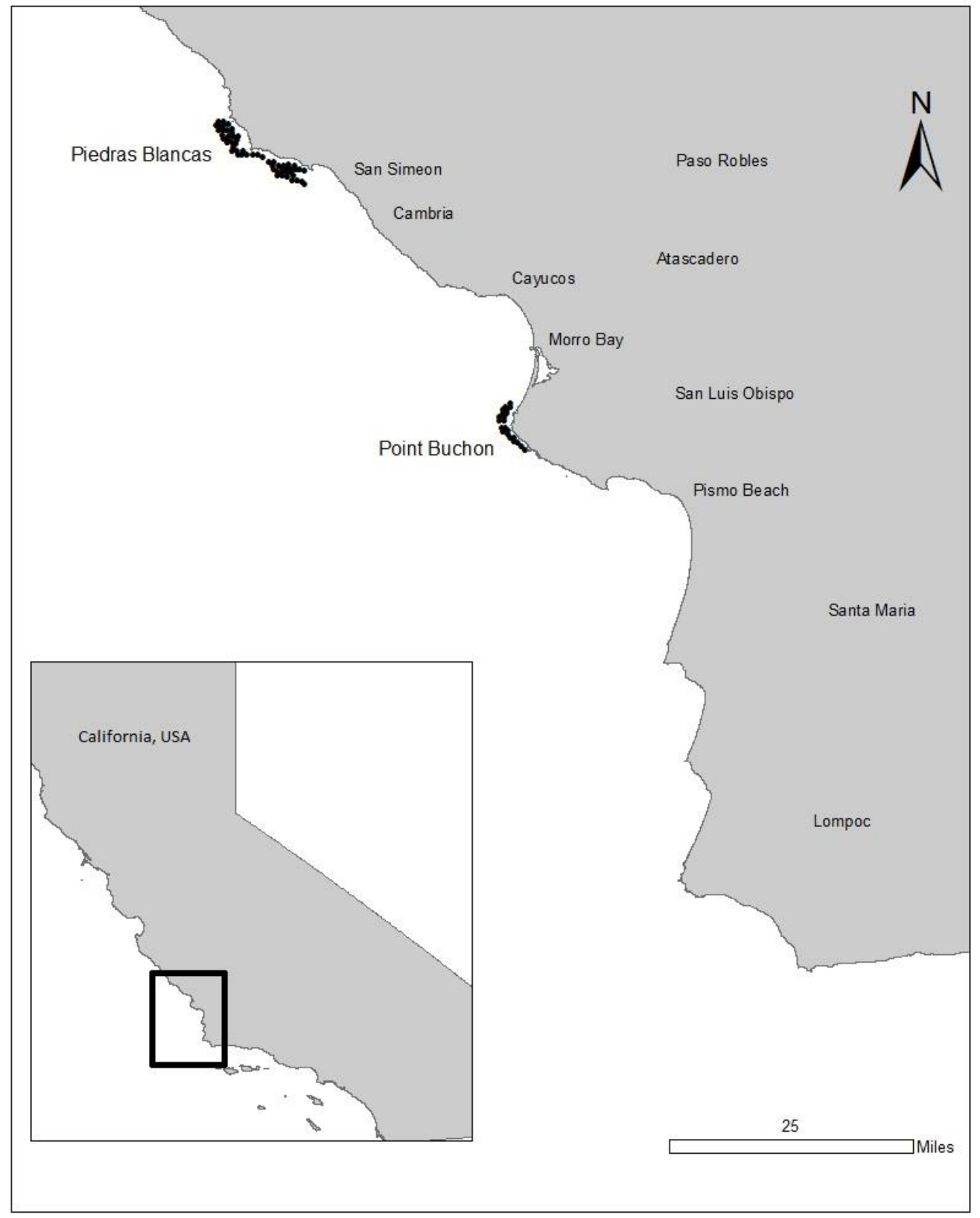

Figure 1. Sampling Sites for Pacific Rockfish off the Central California Coast. Sites were chosen by Cal Poly’s California Collaborative Fisheries Research Project. 

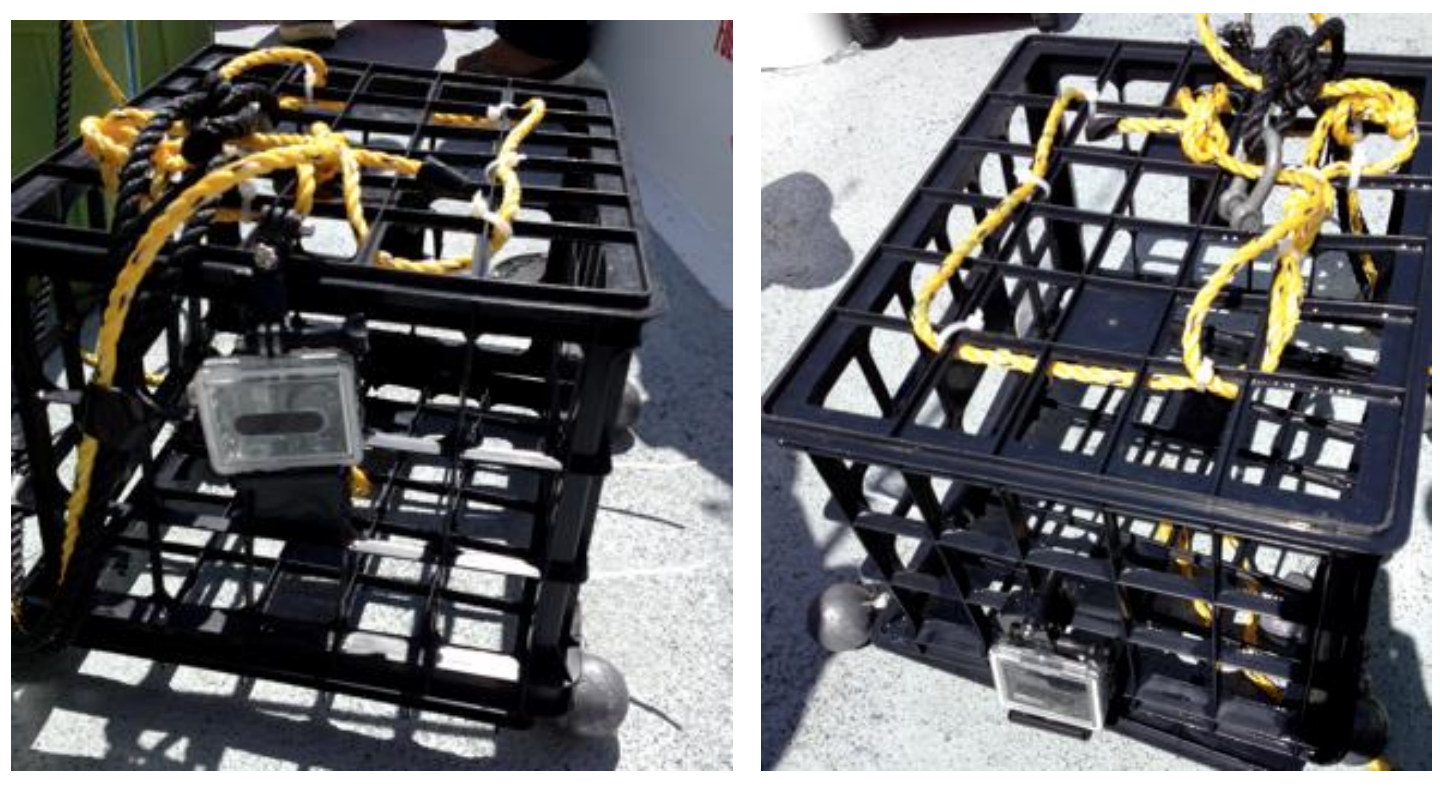

Figure 2. Weighted Inverted Milk Crate Descending Device (Barotrauma Reliever). Two GoPros are attached, one angled upward to view the fish during descend (left), and the other angled downward to view the fish upon release (right). 


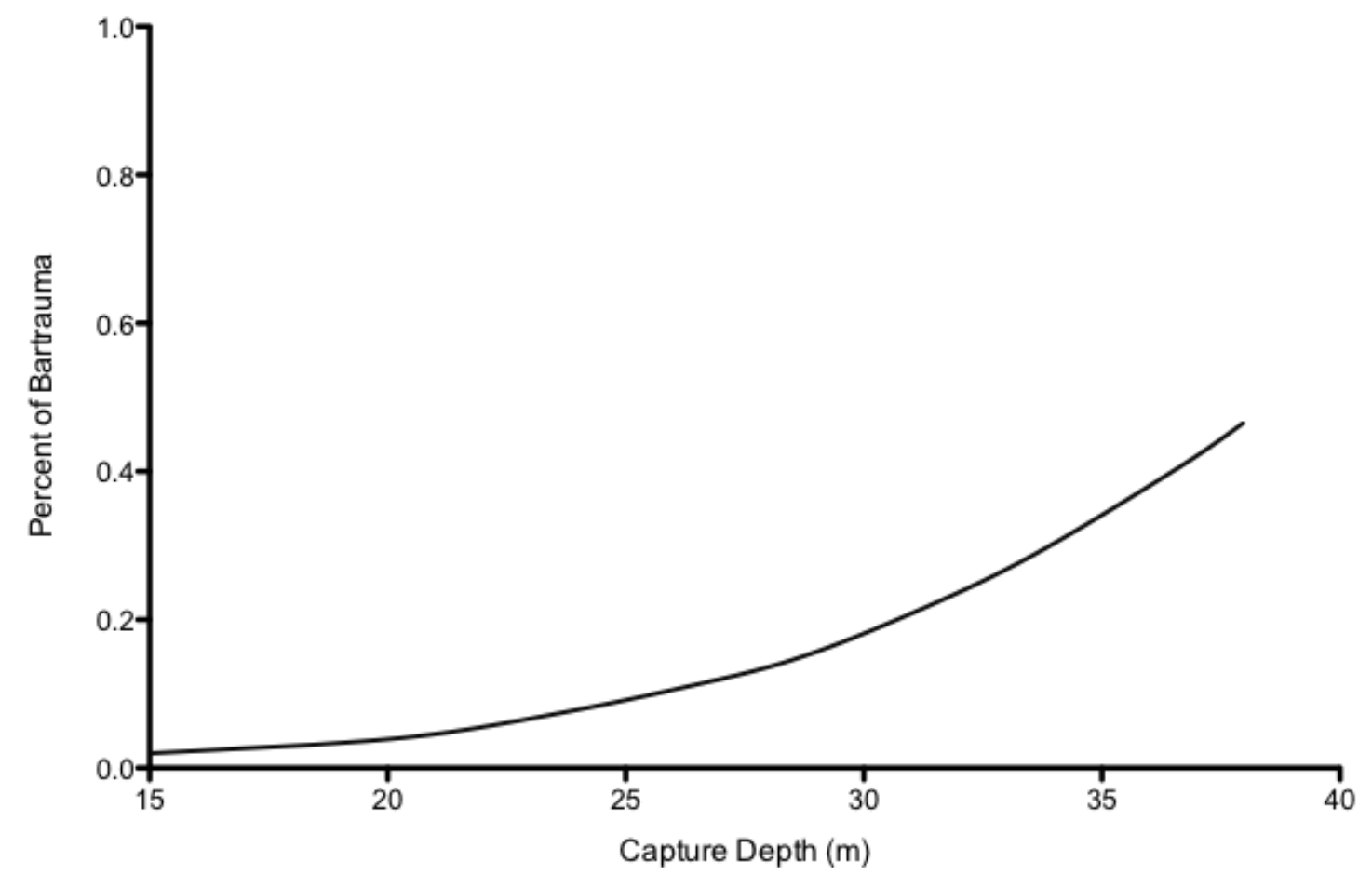

Figure 3. Fitted Logistic Regression Curve Analyzing Correlation of Blue Rockfish Exhibiting Barotrauma in Relation to Capture Depth. See Table 4 for details of statistical tests (slope estimate $=0.0487$, standard error $=0.008$, likelihood ratio $\chi^{2}=36.45$, $\mathrm{P}<0.0001)$. 


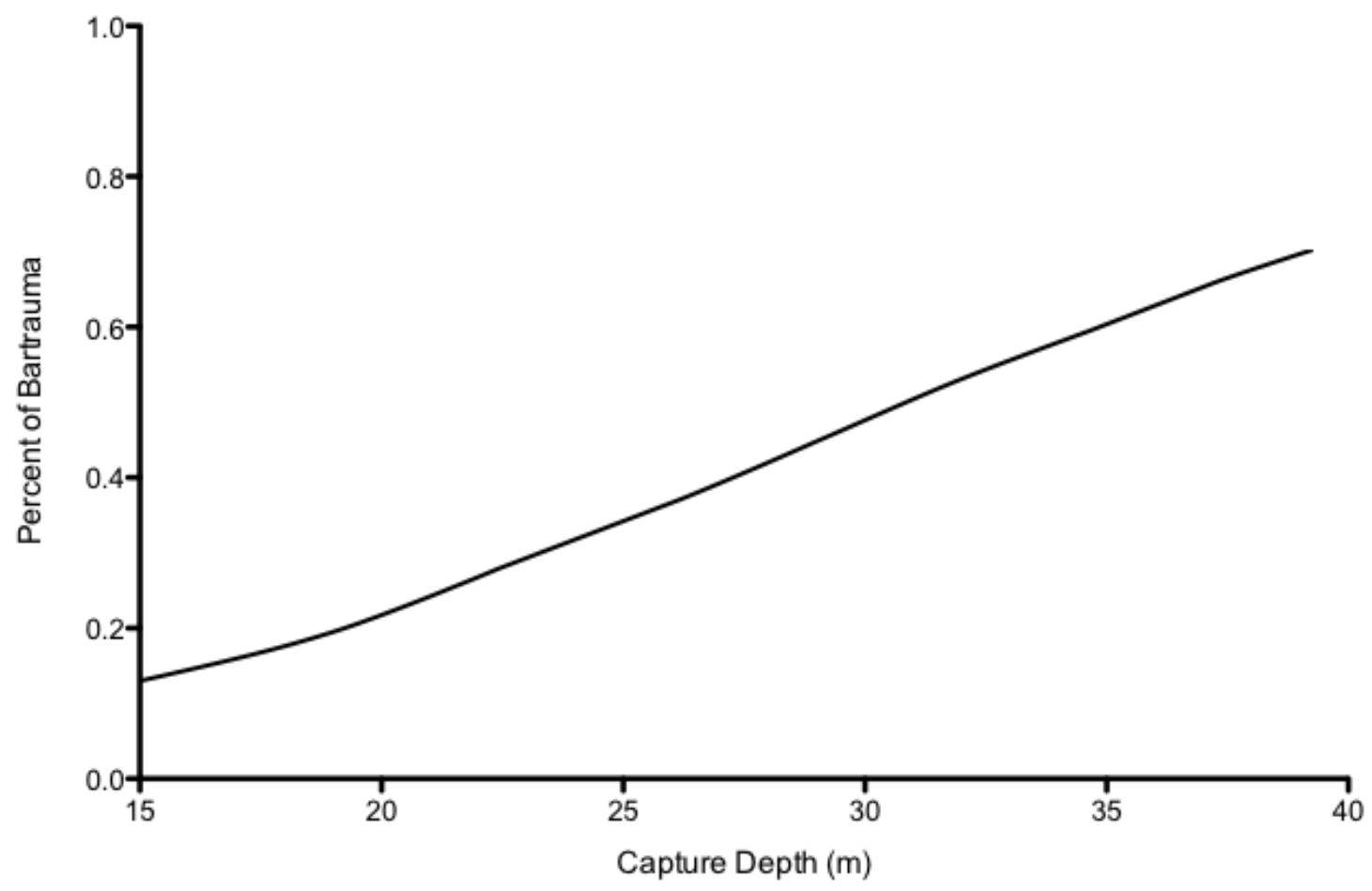

Figure 4. Fitted Logistic Regression Curve Analyzing Correlation of Gopher Rockfish Exhibiting Barotrauma in Relation to Capture Depth. See Table 4 for details of statistical tests (slope estimate $=0.102$, standard error $=0.021$, likelihood ratio $\chi^{2}=23.88, \mathrm{P}<0.0001$ ). 


\section{BIBLIOGRAPHY}

Arnold, G.P., and Walker, M.G. 1992. Vertical movements of cod (Gadus morhua L.) in the open sea and the hydrostatic function of the swim bladder. ICES Journal Marine Science. 49:357-372.

Bartholomew, A., and Bohnsack, J. 2005. A review of catch-and-release angling mortality with implications for no-take reserves. Reviews in Fish Biology and Fisheries.

Brownscombe, J.C., Hyder, K., Potts, W., Wilson, K.L., Pope, K.L., Danylchuk, A.J., Cooke, S.J., Clarke, A., Arlinghaus, R., and Post, J.R. 2019. The future of recreational fisheries: advances in science, monitoring, management, and practice. Fisheries Science 211:247-255.

Bruesewitz, R.E., Coble, D.W., and Copes, F. 1993. Effects of deflating the expanded swim bladder on survival of burbot. North American Journal of Fisheries Management 13:346-348.

Burns, K.M., and Restrepo, V. 2002. Survival of reef fish after rapid depressurization: field and laboratory studies. American Fisheries Society Symposium. 30:148151.

Butcher, P.A., Broadhurst, M.K., Hall, K.C., Cullis, B.R., Raidal, S.R. 2012. Assessing barotrauma among angled snapper (Pagrus auratus) and the utility of release methods. Fisheries Research. 127-128:49-55.

Butcher, D.J., Welch, J.M., Kirkwood, B., Sawynok, and Begg, G.A. 2010. Assessing the effects of line capture and barotrauma relief procedures on post release survival of key tropical reef fish species in Australia using recreational tagging 
clubs. Fisheries Management and Ecology 17:77-88.

California Department of Fish and Wildlife. (2019). Rockfish Barotrauma Information. [Fact sheet]. Retrieved from: https://www.wildlife.ca.gov/conservation/marine/groundfish/barotrauma.

Campbell, M.D., Patino, R., Tolan, J., Strauss, R., and Diamond, S.L. 2010. Sublethal effects of catch-and-release fishing: measuring capture stress, fish impairment, and predation risk using a condition index. ICES Journal Marine Science. 67:513521.

Coleman, F.C., Figueira, W.F., Ueland, J.S., and Crowder, L.B. 2004. The impact of United States recreational fisheries on marine fish populations. Science 305:19581960.

Collins, M.R., McGovern, J.C., Sedberry, G.R., Meister, H.S., and Pardieck, R. 1999. Swim bladder deflation in black sea bass and vermilion snapper: potential for increasing postrelease survival. North American Journal of Fisheries Management. 19:828-832.

Cooke, S.J., and Cowx, I.G. 2004. The role of recreational fishing in global fish crises. BioScience 54:857-859.

Cooke, S.J., Danylchuk, A.J., Danylchuk, S.E., Suski, C.D., and Goldberg, T.L. 2006. Is catch-and-release recreational angling compatible with no-take marine protected areas? Ocean and Coastal Management. 49:342-354.

Cooke, S.J., and Philipp, D.P. 2001. The influence of terminal tackle on injury, handling time, and cardiac disturbance of rock bass. North American Journal of Fisheries Management. 21:333-342. 
Curtis, J.M., Johnson, M.W., Diamond, S.L., and Stunz, G.W. 2015. Quantifying delayed mortality from barotrauma impairment in discarded red snapper using acoustic telemetry. Marine and Coastal Fisheries. 7:434-449.

Davis, M.W. 2005. Behaviour impairment in captured and released sablefish: ecological consequences and possible substitute measures for delayed mortality in discarded or escaped fish. Journal of Fish Biology. 66:254-265.

Davis, M.W. 2002. Key principles for understanding fish bycatch discard mortality. Canadian Journal of Fisheries and Aquatic Science. 59:1834-1843.

Davis, M.W., and Ottmar, M.L. 2006. Wounding and reflex impairment may be predictors for mortality in discarded or escaped fish. Fisheries Research. 2:1-6.

Drumhiller, K.L., Johnson, M.W., Diamond, S.L., Reese Robillard, M.M., and Stunz, G.W. 2014. Venting or rapid recompression increase survival and improve recovery of red snapper with barotrauma. Marine and Coastal Fisheries. 6:190199.

Gitschlag, G.R., and Renaud, M.L. 1994. Field experiments on survival rates of caged and released red snapper. North American Journal of Fisheries Management 14:131-136.

Gotshall, D.W. 1964. Increasing tagged rockfish (genus Sebastodes) survival by deflating the swim bladder. California Department of Fish and Wildlife, 50: 253260.

Green, K., Stahl, J., and Kallenberger, M. 2013. Demersal shelf rockfish remotely operated vehicle survey. Regional Operational Plan CF.1J.2013.09. Anchorage: Alaska Department of Fish and Game. 
Hannah, R.W., and Matteson, K.M. 2007. Behavior of nine species of Pacific rockfish after hook-and-line capture, recompression, and release. Transactions of the American Fisheries Society 136:24-33.

Hannah, R.W., Parker S. J., and Matteson, K.M., 2008a. Escaping the surface: the effects of capture depth on submergence success of surface-released Pacific rockfish. North American Journal of Fisheries Management 28:694-700.

Hannah, R.W., Rankin, P.S., Penny, A.N., and Parker, S.J. 2008b. Physical model of the development of external signs of barotrauma in Pacific rockfish. Aquatic Biology. 3:291-296.

Hazell, J., Krimsky, L., Fluech, B., Staugler, B., Adams, C., Stevely, J., and Botta, R. 2016. Awareness, Knowledge and Perceptions of Barotrauma and Barotrauma Mitigation: A Survey of Florida Anglers. Gainesville, Florida.: Florida Sea Grant College Program.

Hochhalter, S.J., and Reed, D.J. 2011. The effectiveness of deepwater release at improving the survival of discarded yelloweye rockfish. North American Journal of Fisheries Management. 31:852-860.

Jarvis, E.T., and Lowe, C.G. 2008. The effects of barotrauma on the catch-and-release survival of southern California nearshore and shelf rockfish (Scorpaenidae, Sebastes spp.). Canadian Journal of Fisheries and Aquatic Sciences. 65:12861296.

Keniry, M.J., Brofka, W.A., Horns, W.H., and Marsden, J.E. 1996. Effects of decompression and puncturing the gas bladder on survival of tagged yellow perch. North American Journal of Fisheries Management 16: 201-206. 
Kerr, S.J. 2001. A review of "fizzing" - a technique for swim bladder deflation. Fish and Wildlife Branch, Ontario Ministry of Natural Resources, Peterborough, Ontario.

Lea, R.N., McAllister, R.D., and Ventresca, D.A. 1999. Biological aspects of nearshore rockfishes of the genus Sebastes from Central California. California Department of Fish and Game's Fish Bulletin. 177:3-109.

Lewin, W-C., Arlinghaus, R., and Mehner, T. 2006. Documented and potential biological impacts of recreational fishing: insights for management and conservation. Reviews in Fisheries Science. 14:305-367.

Love, M.S., Yoklavich, M., and Thornsteinson, L. 2002. The rockfish of the northeast Pacific. University of California Press, Berkeley.

Lowe, C.G., Anthony, K.M., Jarvis, E.T., Bellquist, L.F., and Love, M.S. Site fidelity of characteristic fish species at offshore oil platforms in the Santa Barbara Channel. MMS OCS Study 2007-006. California State University, Long Beach, California. Morrissey, M.B., Suski, C.D., Esseltine, K.R., and Tufts, B.L. 2005. Incidence and physiological consequences of decompression in smallmouth bass after liverelease angling tournaments.

National Oceanic and Atmospheric Administration. (2019). Southwest Fisheries Science Center [Fact sheet]. Retrieved from: https://swfsc.noaa.gov/barotrauma/.

Nichol, D.G., Chilton, E.A., 2006. Recuperation and behavior of Pacific cod after barotrauma. ICES Journal of Marine Science. 63:83-94.

Pacific Fishery Management Council, Portland, OR. 2006. Amendment 16-4: rebuilding plans for seven depleted Pacific coast groundfish species: final environmental 
impact statement including regulatory impact review and initial regulatory flexibility analysis.

Pacific Fishery Management Council, Portland, OR. 2006. Biological catch and optimum yield specifications and management measures for the 2007-2008 Pacific coast groundfish fishery.

Pacific States Marine Fisheries Commission. 2016. Recreational Fisheries Information Network: RecFIN estimate summary results. RecFIN database. Retrieved from: http://www. psmfc.org/recfin.

Parker, S.J., Berkeley, S. A., Golden, J. T., Gunderson, D.R., Heifetz, J., Hixon, M.A., Larson, R., Leaman, B.M., Love, M.S., Musick, J.A., O'Connell, V.M., Ralston, S., Weeks, H.J., and Yoklavich, M.M. 2000. Management of Pacific Rockfish, Fisheries, 25:3, 22-30.

Parker, S.J., McElderry, H. I., Rankin, P.S., and Hannah. R.W. 2006. Buoyancy regulation and barotrauma in two species of nearshore rockfish. Transactions of the American Fisheries Society 135:1213-1223.

Phillips, S.W. 2007. Synthesis of U.S. Geological Survey Science for the Chesapeake Bay ecosystem and implications for environmental management: U.S. Geological Survey Circular.

Pollock, K.H., and Pine III, W.E. 2007. The design and analysis of field studies to estimate catch-and-release mortality. Fisheries Management and Ecology 14:123-130.

Pribyl, A.L., Kent, M. L., Parker, S. J., and Schreck, C. B. 2011. The Response to forced decompression in six species of Pacific rockfish. Transactions of the American 
Fisheries Society. 140:374-383.

Pribyl, A.L., Schreck, C.B., Kent, M.L., Kelley, K.M., and Parker, S.J. 2012. Recovery potential of black rockfish, Sebastes melanops Girard, recompressed following barotrauma. Journal of Fish Diseases. 35:275-286.

Pribyl, A.L., Schrek, C.B., Kent, M.L., and Parker. S.J. 2009. The differential response to decompression of three species of nearshore Pacific rockfish. North American Journal of Fisheries Management 29:1479-1486.

Rankin, P.S., Hannah, R.W., Blume, M.T.O., Miller-Morgan, T.J., and Heidel, J.R. 2017. Delayed effects of capture-induced barotrauma on physical condition and behavioral competency of recompressed yelloweye rockfish, Sebastes ruberrimus. Fisheries Research. 186:258-268.

Rodgveller, C.J., Malecha, P.W., and Lunsford, C.R. 2017. Long-term Survival and Observable Healing of Two Deepwater Rockfishes, Sebastes, After Barotrauma and Subsequent Recompression in Pressure Tanks. U.S. Department of Commerce. National Oceanic and Atmospheric Administration National Marine Fisheries Service Alaska Fisheries Science Center. (Rodgveller et al., 2017). Rogers, B.L., Lowe, C.G., Fernández-Juricic E. 2011. Recovery of visual performance in rosy rockfish (Sebastes rosceus) following exophthalmia resulting from barotrauma. Fisheries Research. 112:1-7.

Rogers B.L., Lowe C.G., Fernández-Juricic E., Frank L.R. 2008. Utilizing magnetic resonance imaging (MRI) to assess the effects of angling-induced barotrauma on rockfish (Sebastes). Canadian Journal of Fisheries and Aquatic Sciences. 65:1245-1249. 
Rummer, J.L., and Bennett, W.A. 2005. Physiological effects of swim bladder overexpansion and catastrophic decompression on red snapper. Transactions of the American Society. 134:1457-1470.

Ryer, C. H., Ottmar, M. L., and Sturm, E. A. 2004. Behavioral impairment after escape from trawl cod ends may not be limited to fragile fish species. Fisheries Research. 66:261-269.

Sokal, R.R., and Rohlf, F.J. 1995. Biometry the principles and practice of statistics in biological research ( $3^{\text {rd }}$ ed). New York W.H. Freeman.

St. John, J., and J.C. Syers. 2005. Mortality of the demersal West Australian dhufish, Glaucosoma hebraicum (Richardson 1845) following catch and release: the influence of capture depth, venting, and hook type. Fisheries Research. 76:106116.

Sumpton, W.D., Brown, I.W., Mayer, D.G., McLennan, M.F., Mapleston, A., Butcher, A.R., Welch, D.J., Kirkwood, J.M., Sawynok, B., and Begg, G.A. 2010. Assessing the effects of line capture and barotrauma relief procedures on postrelease survival of key tropical reef fish species in Australia using recreational tagging clubs. Fisheries Management and Ecology. 17:77-88.

Theberge, S., and Parker, S.J. 2005. Release methods for rockfish. Oregon Sea Grant, Corvallis, Oregon, No. ORESU-G-05-001.

Wilson, R.R., and Burns, K.M. 1996. Potential survival of released groupers caught deeper than $40 \mathrm{~m}$ based on shipboard and in-situ observations, and tag-recapture data. Bulletin of Marine Science. 58:234-247.

Yoklavich M., Love, M., Forney, K., A fishery-independent assessment of an overfished 
rockfish stock, cowcod (Sebastes levis), using direct observations from an occupied submersible. Canadian Journal of Fisheries and Aquatic Sciences. $12: 1795-1804$ 